Reprod. Nutr. Dévelop., 1985, 25 (3), 521-529.

\title{
Zona-free hamster ovum penetration by human spermatozoa : influence of various sperm factors
}

\author{
Anne-Marie COURTOT, P. JOUANNET
}

Laboratoire d'Histologie-Embryologie-Cytogénétique. Centre Hospitalier, 94270 Le Kremlin-Bicêtre, France.

Summary. The present paper evaluates the influence of various technical factors when preparing human spermatozoa to be tested for their ability to penetrate zona-free hamster ova. Higher in vitro fertilization rates were obtained after sperm selection by " swim-up " migration, 4-h incubation, sperm dilution to a concentration of $2.5 \times 10^{6}$ spermatozoa $/ \mathrm{ml}$, and observation of the oocytes $8 \mathrm{~h}$ after insemination. The use of control samples was necessary because of wide intraindividual and interindividual variations in the results. Unless the result has been confirmed several times, it is impossible to conclude, from a negative test, that a human spermatozoon cannot penetrate a hamster oocyte.

\section{Introduction.}

Mammalian fertilization needs intraspecific gamete recognition. However, some stages of sperm-ovum interaction seem to be analogous in heterospecific in vitro fertilization. In 1976, Yanagimachi et al. obtained swollen human sperm heads and male pronuclei in zona-free hamster oocytes and proposed using this procedure to evaluate human sperm fertilizing ability. The test has been reproduced by many authors (see review in Yanagimachi, 1984 ; Junca, 1984). However, the techniques of sperm preparation are so different from one study to another that it is very difficult to compare the results.

The present study investigated the influence of the sperm selection method, incubation and observation times, and sperm concentration and compared the results obtained using different ejaculates from the same men.

\section{Material and methods.}

Sperm preparation. - Semen samples were collected from 8 volunteers by masturbation at the laboratory. They were selected for the normal values of their semen parameters. Two were of proven fertility. After ejaculation, the samples were left 30 to $60 \mathrm{~min}$ at room temperature to allow liquefaction. 
- Sperm washing: $5 \mathrm{ml}$ of modified Biggers, Whitten and Whittingham (1971) medium (BWW) having an osmolarity of $410 \mathrm{m0sm} / \mathrm{kg}$ and containing $0.8 \%$ of human serum albumin (fraction $\mathrm{V}$, Sigma) were added to $1 \mathrm{ml}$ of semen. The sperm suspension was centrifuged twice at $600 \times \mathrm{g}$ for $5 \mathrm{~min}$ and resuspended in $1 \mathrm{ml}$ of $\mathrm{BWW}$.

- Sperm migration : $1.2 \mathrm{ml}$ of BWW were layered over $1 \mathrm{ml}$ of semen in a test-tube. Great care was taken to maintain an interface. The tube was placed in a $5 \% \mathrm{CO}_{2}, 20 \% \mathrm{O}_{2}, 75 \% \mathrm{~N}_{2}, \mathrm{H}_{2} \mathrm{O}$ saturated atmosphere. After one hour, the upper $1 \mathrm{ml}$ of the BWW fraction was gently removed by aspiration.

- Incubation : the spermatozoa prepared with either method were allowed to incubate at $37{ }^{\circ} \mathrm{C}$ in modified $\mathrm{BWW}$ in a $5 \% \mathrm{CO}_{2}, 20 \% \mathrm{O}_{2}, 75 \% \mathrm{~N}_{2}, \mathrm{H}_{2} \mathrm{O}$ saturated atmosphere for $4 \mathrm{~h}$. They were diluted to a final concentration of $2.5 \times 10^{6}$ or $0.5 \times 10^{6}$ spermatozoa $/ \mathrm{ml}$, depending on the method, and then put in contact with the oocytes.

Oocyte preparation. - Female golden hamsters were induced to superovulate by intraperitoneal injection of 30 IU of pregnant mare gonadotropin (PMSG, Sigma) on day 1 and $30 \mathrm{IU}$ of human chorionic gonadotropin (hCG, Organon) on day 3. Sixteen to $18 \mathrm{~h}$ after hCG administration, the animals were sacrificed with ether. The oocytes were removed from the oviducts and placed in the culture medium. The cumulus and zona layers of the collected oocytes were removed by treatment in the medium with 0.1 hyaluronidase (Type I, Sigma) for $10 \mathrm{~min}$ and then with $0.05 \%$ trypsin (Type I, Sigma) for about 2 min. After each enzyme treatment, the oocytes were washed 3 times in the culture medium.

Insemination. - Droplets of $200 \mu \mathrm{l}$ each of sperm suspension were placed in sterile plastic dishes (Corning, $60 \mathrm{~mm}$ diameter). Approximately 20 zona-free hamster oocytes were added to each droplet and the mixture was incubated at $37{ }^{\circ} \mathrm{C}$ in a $5 \% \mathrm{CO}_{2}, 20 \% \mathrm{O}_{2}, 75 \% \mathrm{~N}_{2} \mathrm{H}_{2} \mathrm{O}$ saturated atmosphere. The zona-free oocytes were removed 3 and $8 \mathrm{~h}$ after insemination, washed 3 times in the medium, and observed under a microscope using phase or interferential contrast (1000 × Univar-Reichert).

Parameters studied. - Various images were observed: attached spermatozoa, swollen sperm heads, and male pronuclei (plate I, photos A, B, C). Further experiments on attached spermatozoa are needed. The human male pronucleus could be easily distinguished from the hamster female pronucleus by the presence of a tail. However, the tail does not always remain attached to the male pronucleus, and the female pronucleus may be fragmented (Yanagimachi, 1984) making interpretation difficult. Therefore, we used only ova in which the swollen sperm heads were clearly visible in the egg ooplasm.

PLATE 1. - Interaction of human spermatozoa and zona-free hamster ova.

A : Most of the spermatozoa are attached to the oocyte membrane (F); some of them have penetrated the cytoplasm and present a swollen head (SW). Interferential contrast $\times 1000$.

B : A pronucleus in the ooplasm. Interferential contrast $\times 1000$.

C : Pronuclei in the ooplasm. Probably resulting from the fragmentation of an initial pronucleus. Interferential contrast $\times 1000$. 

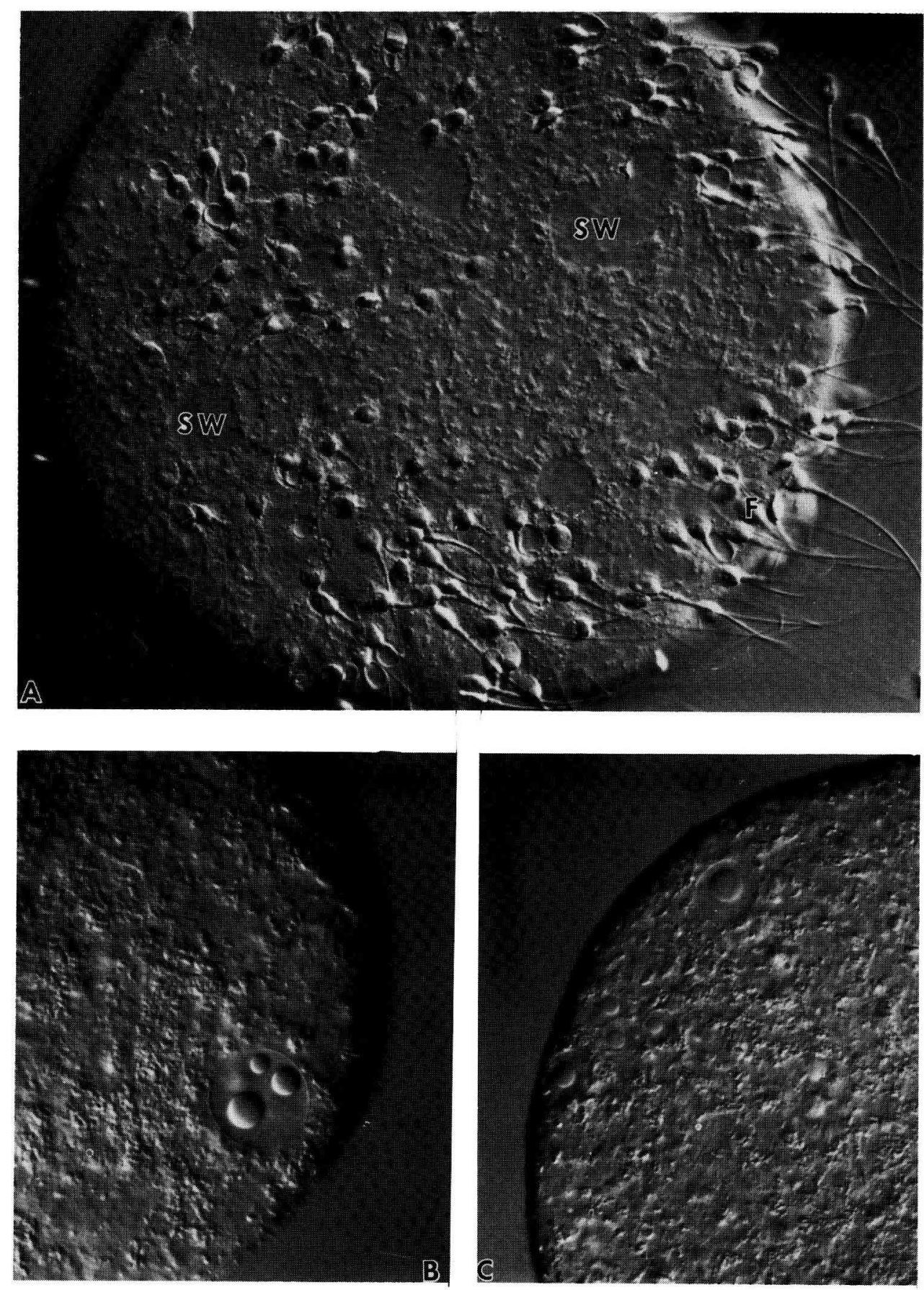
Statistical analysis. - Sperm preparation methods, incubation times and sperm concentrations were statistically analysed using Student's t-test on paired data from each subject. For comparing the observation times, we used the Bartlett test (Snedecor and Cochran, 1971).

\section{Results.}

Influence of sperm characteristics. - The mean characteristics of the semen samples used in this study were : volume $3.3 \pm 1 \mathrm{ml}$; motility $53 \pm 11 \%$; vitality $83.8 \pm 7 \%$; concentration $126 \pm 38 \times 10^{6} \mathrm{ml}$. We did not find any correlation between the initial percentage of motile spermatozoa or sperm concentration and the percentage of oocytes with swollen sperm heads (25 ejaculates).

Influence of the sperm selection method. - In 14 samples, we compared the percentages of oocytes penetrated by migrated spermatozoa $\left(2.5 \times 10^{6}\right.$ cells $\left./ \mathrm{ml}\right)$ and washed spermatozoa $\left(2.5 \times 10^{6} \mathrm{cells} / \mathrm{ml}\right)$ after $4 \mathrm{~h}$ of incubation. Since a significantly higher rate of penetrated oocytes was obtained in the "swim-up " population (51 vs $26 \% ; P<0.001$ ) we retained this preparation method for a study of the other factors.

Influence of sperm concentration. - The penetration ability of $0.5 \times 10^{6}$ and $2.5 \times 10^{6}$ inseminated spermatozoa per $\mathrm{ml}$ was evaluated in six different samples after $4 \mathrm{~h}$ of incubation. Although better results were obtained with $2.5 \times 10^{6}$ cells $/ \mathrm{ml}$, the difference was not significant after either 3 or $8 \mathrm{~h}$ (fig. 1).

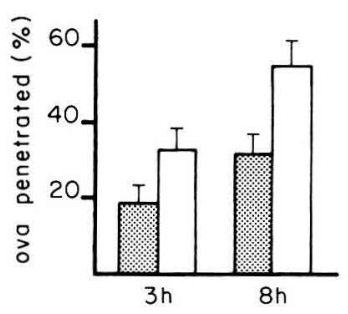

FIG. 1. - Influence of the concentration of inseminated spermatozoa on the percentage of penetrated hamster oocytes (mean \pm SEM) 3 or $8 \mathrm{~h}$ after insemination.

鴊 $=0.5 \times 10^{6}$ spermatozoa $/ \mathrm{ml}$;

$\square=2.5 \times 10^{6}$ spermatozoa $/ \mathrm{ml}$.

Influence of incubation time. - The influence of incubation time was tested in 11 semen samples from 5 men. In all cases, the number of penetrated oocytes was significantly higher ( 37 vs $8 \% ; P<0.01$ ) after $4 \mathrm{~h}$ of incubation compared to $0 \mathrm{~h}$, i.e. when the spermatozoa were inseminated immediately after " swimup $»$ migration in BWW.

Influence of observation time. - In 35 semen samples from 7 men 13 to 8 for each man), we tested the influence of the time-lag between insemination and the time the oocytes were analysed. Incubation time was $4 \mathrm{~h}$ in all cases. 
The results varied among the subjects as shown in figure 2 . In 3 cases (subjects 1, 3 and 6), the mean percentages of penetrated oocytes did not exceed $50 \% 3$ and $8 \mathrm{~h}$ after insemination, and the results were not significantly different between the two observation times. In 2 cases (subjects 4 and 7), the percentages of penetrated oocytes were high as early as $3 \mathrm{~h}$ after insemination. In the last 2 cases (subjects 2 and 5), there was a marked increase in the percentages of penetrated oocytes at $8 \mathrm{~h}$.

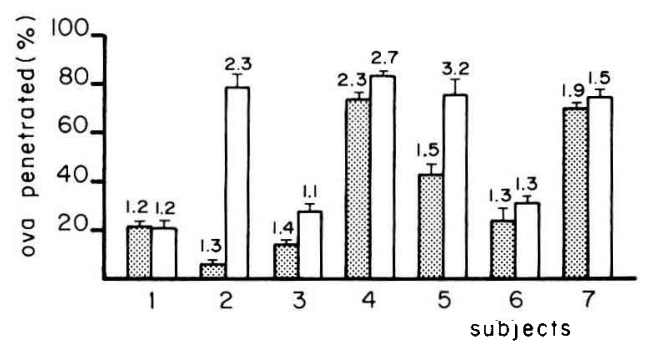

FIG. 2. - Influence of observation time after insemination on the percentage of penetrated hamster oocytes (mean \pm SEM).

Numbers over bars indicate the mean number of swollen sperm heads per penetrated oocyte.

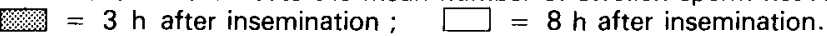

Although some of the swollen sperm heads might have been transformed into pronuclei as late as $\mathbf{8 h}$ after insemination, the mean percentage of oocytes with decondensed sperm heads did not decrease. In all cases but 2 (subjects 2 and 5), the mean number of swollen sperm heads per ovum was the same regardless of the time of observation.

Reproducibility of the test with various semen samples from the same donor. In most cases, large variations in the percentages of penetrated oocytes were observed in different semen samples from the same subject (table 1). If we consider $20 \%$ as the lowest limit of a positive test, as is generally the case (Hall, 1981 ) only 3 subjects always showed a positive test. In one case (subject 2), the test was always negative $3 \mathrm{~h}$ after insemination but positive $8 \mathrm{~h}$ after. The sperm from 3 men (subjects 1, 3 and 6) gave variable results.

TABLE 1

Variation in the \% of penetrated oocytes observed with spermatozoa from the various ejaculates of 7 men. The test was positive if more than $20 \%$ of the oocytes were penetrated.

\begin{tabular}{cccccc}
\hline \multirow{2}{*}{$\begin{array}{c}\text { Subject } \\
\text { number }\end{array}$} & \begin{tabular}{c} 
Observation $3 \mathrm{~h}$ \\
\cline { 2 - 3 }
\end{tabular} & $\begin{array}{c}\text { After insemination } \\
\text { oocytes (Range) }\end{array}$ & $\begin{array}{c}\text { Observation } 8 \mathrm{~h} \\
\text { oositive tests }\end{array}$ & $\begin{array}{c}\text { \% of penetrated } \\
\text { oocytes (Range) }\end{array}$ & $\begin{array}{c}\text { Number of } \\
\text { positive tests }\end{array}$ \\
\hline 1 & $3-41$ & $3 / 8$ & $0-77$ & $2 / 8$ \\
2 & $0-10$ & $0 / 5$ & $64-95$ & $3 / 3$ \\
3 & $0-29$ & $1 / 5$ & $4-40$ & $4 / 5$ \\
4 & $28-100$ & $8 / 8$ & $71-100$ & $7 / 7$ \\
5 & $23-70$ & $4 / 4$ & $46-98$ & $4 / 4$ \\
6 & $5-68$ & $1 / 5$ & $12-43$ & $3 / 5$ \\
7 & $60-80$ & $3 / 3$ & $64-82$ & $3 / 3$ \\
\hline
\end{tabular}




\section{Discussion.}

Human spermatozoa must be removed from the seminal plasma before their ability to penetrate zona-free hamster oocytes can be tested. In most cases, this procedure combines centrifugation and dilution of the pellet in the culture medium, leading to an unselected population of sperm cells. Some authors select motile spermatozoa by their active " swin-up " migration from the seminal plasma to the culture medium (Barros et al., 1979; Gould et al., 1983 ; Pilikian, 1983 ; Tyler et al., 1981 ; Wolf and Sokolski, 1982). With this method the conditions are comparable to the physiological situation in which spermatozoa have to move actively through the cervical mucus before reaching the oocytes. Mortimer et al. (1984) have shown that " swim-up " migration increases the percentage of motile cells. The results obtained here confirm their findings. We also observed a morphological selection of spermatozoa after migration, the mean percentage of normal cells being 78 (67 to 93 ) vs 59 (47 to 74 ) in the semen. Such selection is also known to occur in the cervical mucus (Jeulin et al., 1984). Since the oocyte penetration rate was higher when " swin-up " migration was used to select the spermatozoa, we found this method more suitable for the test.

The penetration rate was related to the concentration of spermatozoa put in contact with the oocytes. Binor et al. (1980) found that the number of incorpored spermatozoa was expressed as a function of the log of the concentration of motile spermatozoa for concentrations ranging from $6 \times 10^{5}$ to $5 \times 10^{6} / \mathrm{ml}$. According to Tyler et al. (1981), the rate of oocytes penetrated by spermatozoa prepared by "swim-up " migration was not influenced by sperm concentrations of $1 \times 10^{6}$ to $8 \times 10^{6} / \mathrm{ml}$. Using unselected spermatozoa, Martin and Taylor (1983) observed a decrease in the penetration rate at a sperm concentration of $5 \times 10^{5} / \mathrm{ml}$. Using selected and mainly motile spermatozoa at a concentration of $2.5 \times 10^{6} \mathrm{cells} / \mathrm{ml}$, we observed a good penetration rate of $55.1 \%$. Our experimental conditions were optimal (penetration rate : $100 \%$ ) in only some cases of the studied population, but with this concentration the number of spermatozoa attached to the oocyte membrane did not prevent the investigator from clearly observing the nuclear decondensation of incorporated spermatozoa so that comparative studies could be carried out.

The mean penetration rate was lower at a sperm concentration of $0.5 \times$ $10^{6} / \mathrm{ml}$ as compared to a sperm concentration of $2.5 \times 10^{6} / \mathrm{ml}(31.9$ vs $55.1 \%)$. This must be kept in mind, especially when testing spermatozoa swimming up with low efficiency, as shown for instance in human spermatozoa lacking outer dynein arms (Courtot et al., 1984).

Modified BWW medium with an osmolarity of $410 \mathrm{mOsm}$ was used in this study. Aitken et al. (1983) have shown that the use of this medium improves the acrosome reaction and the percentage of penetrated zona-free hamster oocytes, and they recommended a total assay time of $6 \mathrm{~h}$ for routine use. Higher penetration rates could be obtained with longer incubation times (Johnson and Alexander, 1984). However, no study has been carried out using an hyperosmotic medium. 
With a modified BWW medium supplemented with $0.8 \%$ human serum albumin, we found a significantly higher penetration rate when the incubation time was $4 \mathrm{~h}$ and the observation time after insemination $8 \mathrm{~h}$ as compared to 0 and $3 \mathrm{~h}$, respectively. Nevertheless, in some cases the penetration rate was $20 \%$ as early as $3 \mathrm{~h}$ after insemination. Our results support those of Perreault and Rogers (1982) who showed that the spermatozoa required a certain time for capacitation and that that time varied with the subject.

Test reliability has been studied by several authors (Binor et al., 1980 ; Cohen et al., 1982 ; Hall, 1981 ; Junca et al., 1982 ; Karp et al., 1981 ; Tyler et al., 1981 ; Zausner-Guelman et al., 1981). Rogers et al. (1983) distinguished men whose spermatozoa penetrated hamster oocytes at a constant (high or low) rate from those men whose penetration rate varied. Our study confirms these results. The penetration rate (independant of incubation and observation times) was higher than $20 \%$ in all the ejaculates of only 3 of the 7 men studied. Intra-individual variations depended on factor(s) unknown to us since we could not find any explanation related to sperm characteristics or to female factors; in our experiment, the oocytes from different animals were pooled in order to avoid any distortion related to the penetration rate due to variations in oocyte quality. Besides, intra-assay variability has already been studied by Tyler et al. (1981).

For a valid interpretation of the results and from a practical viewpoint, technical factors should be taken into consideration, particularly when spermatozoa lacking outer dynein arms are tested; the low percentage of penetrated hamster oocytes may be related to a low concentration of migrated spermatozoa. It is impossible to conclude from one negative test that a human spermatozoon is unable to penetrate an oocyte; it has to be confirmed several times.

\section{Conclusion.}

The selection of spermatozoa by "swim-up " migration, 4-hour incubation, observation of the oocytes $8 \mathrm{~h}$ after insemination, reproducibility of the procedure and the use of control samples seem to be good criteria for testing the ability of human spermatozoa to penetrate zona-free hamster oocytes at a concentration of $2.5 \times 10^{6}$ spermatozoa $/ \mathrm{ml}$. Should these factors be modified, especially in the case of pathological samples, great care must be taken in interpreting the results.

Reçu en septembre 1984. Accepté en janvier 1985.

Acknowledgements. - We would like to thank Mr. P. Caut for his very good technical collaboration, Mr. J. L. Huret and Mr. D. Schoevaert for their assistance in statistics and Mrs. F. Siryani for helping to translate and edit the paper.

This work was supported by grant $\mathrm{N}^{\circ} 311$ from UER Kremlin-Bicêtre, France. 
Résumé. Pénétration de spermatozoïdes humains dans les ovocytes dépellucidés de hamster. Etude de différents facteurs spermatiques.

Nous avons mesuré l'influence de différentes conditions techniques de préparation du sperme sur la capacité de pénétration des spermatozoïdes humains dans les ovocytes dépellucidés de hamster. De meilleurs résultats ont été obtenus par migration ascendante et incubation pendant 4 heures lorsque I'on utilise des spermatozoïdes humains à la concentration de $2,5 \times 10^{6} / \mathrm{ml}$. L'utilisation de spermes témoins est nécessaire du fait de la variabilité intra et inter-individuelle des résultats. II n'est pas possible d'affirmer que le sperme d'un sujet donné est incapable de pénétrer dans les ovocytes de hamster à partir d'un résultat négatif à moins qu'il n'ait été confirmé plusieurs fois.

\section{References}

AITKEN R. J., WANG Y. F., LIU J., BEST F., RICHARDSON D. W., 1983. The influence of medium composition, osmolarity and albumin content on the acrosome reaction and fertilizing capacity of human spermatozoa : development of an improved zona-free hamster egg penetration test. Int. J. Androl., 6, 180-193.

BARROS C., GONZALEZ J., HERRERA E., BUSTOS-OBREGON E., 1979. Human sperm penetration into zona-free hamster oocytes as a test to evaluate the sperm fertilizing ability. Andrologia, 11, 197-210.

BIGGERS J. D., WHITTEN W. K., WHITTINGHAM D. G., 1971. The culture of mouse embryos in vitro, 86-116. In DANIEL J. C. Jr., Methods in mammalian embryology. Freeman, San Francisco.

BINOR Z., SOKOLSKI J. E., WOLF D. P., 1980. Penetration of the zona-free hamster egg by human sperm. Fertil. Steril,, 33, 321-327.

COHEN J., WEBER R. F. A., VAN DER VIJVER J. C. M., ZEILMAKER G. H., 1982. In vitro fertilizing capacity of human spermatozoa with the use of zona-free hamster ova : interassay variation and prognostic value. Fertil. Steril., 37, 565-572.

COURTOT A. M., JEULIN C., ESCALIER D., SERRES C., FENEUX D., JOUANNET P., 1984. Ability of human spermatozoa without dynein arms to penetrate zona-free hamster oocytes. In Int. Symp. on human in vitro fertilization. Actual problems and prospects, Cargese. Elsevier (in press).

GOULD J. E., OVERSTREET J. W., YANAGIMACHI H., YANAGIMACHI R., KATZ D. F., HANSON F. W., 1983. What functions of the sperm cell are measured by in vitro fertilization of zona-free hamster eggs ? Fertil. Steril., 40, 344-352.

HALL J. L., 1981. Relationship between semen quality and human sperm penetration of zona-free hamster ova. Fertil. Steril., 35, 457-463.

JEULIN C., SOUMAH A., JOUANNET P., 1985. Morphological factors influencing the selection of human spermatozoa into cervical mucus in vitro. Int. J. Androl. (in press).

JOHNSON J. P., ALEXANDER N. J., 1984. Hamster egg penetration : comparison of preincubation periods. Fertil. Steril., 41, 599-602.

JUNCA A. M., 1984. Evaluation de la fécondance du sperme humain par la fécondation in vitro interspécifique. Corrélation avec la fécondation in vitro humaine. Th. $3^{\circ}$ cycle, Paris VI.

JUNCA A. M., MANDELBAUM J., PLACHOT M., DE GROUCHY J., 1982. Evaluation de la fécondance du sperme humain par la fécondation in vitro interspécifique (homme-hamster). Ann. Genét., 25, 91-95.

KARP L. E., WILLIAMSON R. A., MOORE D. E., KIRKWOOD K. S., PLYMATE S. R., SMITH W. D., 1981. Sperm penetration assay : useful test in evaluation of male fertility. Obstetr. Gynecol., 57, 620-623.

MARTIN R. H., TAYLOR P. J., 1983 Effect of sperm concentration in the zona-free hamster ova penetration assay. Fertil. Steril., 39, 379-381. 
MORTIMER D., COURTOT A. M., GIOVANDRANDI Y., JEULIN C., DAVID G., 1984. Human sperm motility after migration into and incubation in synthetic media. Gamete Res., 9, 131-144.

PERREAULT S. D., ROGERS B. J., 1982. Capacitation pattern of human spermatozoa. Fertil. Steril., 38, 258-260.

PILIKIAN S., 1983. Etude des differentes concentrations de glycérol sur la mobilité et la vitesse des spermatozoïdes après décongélation. Evaluation du pouvoir fécondant. Mémoire DERBH, Univ. Claude Bernard, Lyon I.

ROgers B. J., PERREAULT S. D., BENTWOOD B. J., McCARVILle C., hale R. W., SODERDAHL D. W., 1983. Variability in the human-hamster in vitro assay for fertility evaluation. Fertil. Steril., 39, 204-211.

SNEDECOR G. W., COCHRAN W. R., 1971. Statistical methods. lowa State Univ. Press, Ames.

TYLER J. P. P., PRYOR J. P., COLLINS W. P., 1981. Heterologous ovum penetration by human spermatozoa. J. Reprod. Fertil., 63, 499-508.

WOLF D. P., SOKOLSKI J. E., 1982. Characterization of the sperm penetration bioassay. J. Androl., 3, 445-451.

YANAGIMACHI R., 1984. Zona-free hamster eggs : their use in assessing fertilizing capacity and examining chromosomes of human spermatozoa. Gamete Res., 10, 187-232.

YANAGIMACHI R., YANAGIMACHI H., ROGERS B. J., 1976. The use of zona-free animal ova as a test system for the assessment of the fertilizing capacity of human spermatozoa. Biol. Reprod., 15, 471-476.

ZAUNSNER-GUELMAN B., BLASCO L., WOLF D. P., 1981. Zona-free hamster eggs and human sperm penetration capacity : a comparative study of proven fertile donors and infertility patients. Fertil. Steril., 36, 771-777. 